\title{
Formulation, Preparation, Physico-Chemical, Microbiological Analysis and Clinical Uses of Capsaicin Microemulsions
}

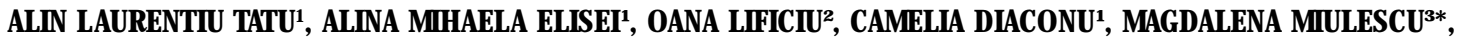 \\ OLIMPIA DUMITRIU BUZIA ${ }^{1 *}$ \\ ${ }^{1}$ Dunarea de Jos University, Faculty of Medicine and Pharmacy, Research Center in the Field of Medical and Pharmaceutical \\ Sciences, 35 Al. I. Cuza Str., 800010, Galati, Romania \\ ${ }^{2}$ College of Pharmacists, 27 Galati Str., 810388, Galati, Romania \\ 3Dunarea de J os University of Galati, Faculty of Medicine and Pharmacy, Department of Morphological and Functional Sciences, \\ 35 Al. I. Cuza Str, 800010, Galati, Romania

\begin{abstract}
The present paper aims at creating a pharmaceutical formulation, i.e. microemulsion with capsaicin as the active principle; the purpose was to solubilize capsaicin and draw up pseudoternary phase diagrams establishing the microemulsion domains. We created a pharmaceutical form: capsaicin ointment, aiming at releasing capsaicin in the microemulsion and ointment bases. Comparative microbiological determinations were performed between microemulsion and ointment. The novelty of the study is formulating microemulsions as a means of solving solubility issues and increasing the bioavailability of medicinal substances.
\end{abstract}

Keywords:capsaicina, microemulsion, gram negative germs, gram positive germs

The purpose of the paper is the answer to an urgent need of today's scientific community, i.e. applying nanotechnologies to medicine functionalization. In this respect, we aimed at including capsaicin in stable nanostructured thermodynamic systems of the microemulsion (nanoemulsion) type, in order to obtain a pharmaceutical form with potential topical application. Last but not least, we can create retard disperse encapsulated systems applicable in various forms of cancer.

\section{Experimental part}

Materials and methods

\section{Capsaicin $\mathrm{C}_{18} \mathrm{H}_{27} \mathrm{O}_{3} \mathrm{~N}$}<smiles>COc1cc(CNC(=O)CCCCC/C=C/C(C)C)ccc1O</smiles>

Chemically speaking, capsaicin is 8-methyl-N-vanillyl6-nonenamide.

Capsaicin, the active component in chilli pepper (Capsicum annuum) is an alkaloid containing $0.02-0.03 \%$ capsaicin, giving the pepper its spicy burning taste. It is an irritant to the mammalian epithelium, creating a burning sensation in the mouth, which may be considered a spicy taste element. Plants produce capsaicin in order to discourage their consumption by animals[1] .

In medicine, internally used capsaicin intensifies the activity of the suprarenal cortex and the secretion of corticosteroid hormones, stimulating digestion. Intravenously administered capsaicin produces apnea and blood pressure decrease. Externally, capsaicin alcoholic tincture or various lotions, skin patches or creams are used in treating chronic pain (diabetic neuropathy, post-zoster algias, other neuralgias, joint pains, lumbago, bladder hypersensitivity) and itching associated to certain dermatoses (anal itching, etc.) or terminal renal failure. $[2,3]$.The antalgic action mechanism is given by the inhibiting action upon substance $P$.
Applying capsaicin on the skin in moderate doses triggers a heating sensation, and in high doses a burning sensation. Certain Italian studies show the important role of orally-administered capsaicin in bladder cancer as it causes the death of cancer cells [4].Capsaicin is a blood stream activator as well as an anti-inflammatory agent in rhumatismal processes, like ibuprofen [5-7], diclofenac, profenid, black pepper, curcumin, hotpepper etc. Capsaicin introduced in the blood stream through gel as a pharmaceutical formula plays a part in reducing internal bleeding, healing gastro-duodenal ulcers and protecting against haemorrhagic strokes[8].Studies carried out at Harvard University indicate the use of capsaicin in treating neuropathic pain in postherpetic neuralgia. Itmay be used for atypical facial pain (caused by the irritation of the trigeminal nerve innervating the face area). Another role of capsaicin is stimulation of the immune system. Administering capsaicin attracts the cells of the immune system that help destroy bacteria making it useful in antibiotic-resistant infections, and inactivating toxic substances issued from cellular destruction and adverse allergic and non-allergic reactions, the potential adverse effects of common drugs being well-known in medical practice of various specialties [9-21] A study performed in India showed that a diet rich in spices and chilli peppers (with high capsaicin levels) and low in proteins leads to good results in decreasing body weight and normalizing triglycerides in the body.

The most commonly used capsaicin doses that were clinically tested in treating neuropathic pains range between $0.025 \%, 0.075 \%$ and $0.1 \%$ and under gel form [22]

We used capsaicin in concentrations of 1 and $5 \%$ that we introduced in the microemulsion and the ointment bases ( 1.5 and $10 \%$ )

The microemulsion contains: Oil phase: Flaxseed oil + capsaicin (3:1); Aqueous phase: distilled water + glycerine (4:1); Emulsifier: Tween 80 ;Coemulsifier: ethyl alcohol

The ointment bases: I(1\%), II(5\%), III (10\%) contain (tab.1) the following: 
Table 1

CONTENT OF OINTMENT BASES

\begin{tabular}{|c|c|c|c|}
\hline Components & \multicolumn{3}{|c|}{ Formula } \\
\cline { 2 - 4 } (g) & I & II & III \\
\hline Lanolin & $\mathbf{2}$ & $\mathbf{2 . 5}$ & $\mathbf{5}$ \\
\hline Vaseline & 17.8 & 16.3 & - \\
\hline Cholesterol & - & $\mathbf{0 . 2}$ & 1.25 \\
\hline Cetaceum & - & - & 4 \\
\hline Paraffin oil & - & - & $\mathbf{7 . 7 5}$ \\
\hline Capsaicin & $\mathbf{0 . 2}$ & 1 & $\mathbf{2}$ \\
\hline
\end{tabular}

Other materials:distilled water,glycerol,flaxseed oil,ethyl alcohol,tween,coemulsifiers.

The lipophilic phase is made up of aliphatic, aromatic hydrocarbons, esters, triglycerides, vegetable oils, lanolin, fatty alcohols, mineral fats, as well as various lipophilic substances.

Emulsifiers are selected according to the administering manner. Ionic, non-ionic and amphoteric derivatives are used, such as: sorbitan esters, ethylated fatty alcohols, saturated $\mathrm{C}_{8}-\mathrm{C}_{10}$ polyglycolized glycerides, saccharose esters, PEG ethers and esters, betains and lecithins.

Coemulsifiers: alcohols, glycols, propylene glycol derivatives, polyglycerol derivatives, aromatic alcohols like benzyl alcohol, aliphatic polyols like ethyl-2-hexandiol 1,3 and glycol esters.

\section{Ointment bases}

Ointment bases are made up of excipient mixtures, and rarely of just one. Quantitatively speaking, they account for the most part of an ointment and give the preparation the desired consistency [23]

The most precise and modern method of microemulsion preparation is based on establishing pseudoternary diagram, that had the emulsifier (surfactant - S)/ coemulsifier (cosurfactant - CoS) (S/COS) ratio fixed [24].

These pseudoternary phase diagrams vary the ratio of water, oil, emulsifier, coemulsifier, determining the area where the formation of microemulsion takes place.

Drawing up a phase diagram, to the purpose of localising the microemulsion areas, is practically achieved through titration. Starting from a definite S/COS ratio, various mixtures are made between the lipophilic phase and S/ CoS. In this system the aqueous phase is added drop by drop. After each addition, the mixture is gently stirred, for homogenization purposes, then examined between crosspolarized filters. The optical aspect is noted: transparency, opalescence, isotropy and phase number. Thus we obtain a definition of borders that may achieve mixtures, point by point, starting from 4 components.

Pseudoternary diagrams are used, in which two components are grouped in order to form a pure pseudo constituent. A constant emulsifier/coemulsifier ratio is commonly used as a pseudoternary constituent. Tracing the specific concentrations water/oil/surfactant may be used by means of figure 1 .

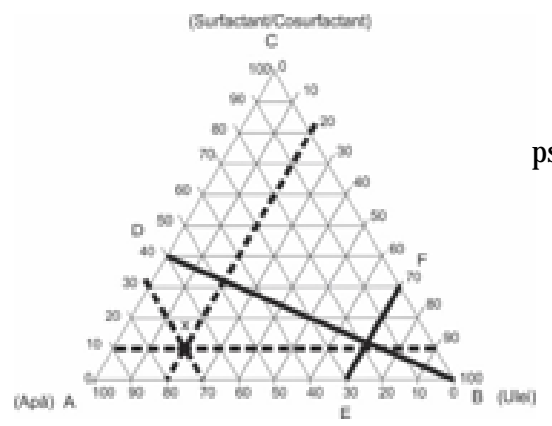

\section{Results and discussions}

In order to prepare the capsaicin microemulsion we drew up the phase pseudoternary diagrams by means of which the mixture ratios were found. The phase diagrams varied the ratio of water, oil, emulsifier and coemulsifier and determined the area where the microemulsion was formed.

It was found to be stable in the mixing ratio oil (0), water (W), emulsifier (surfactant-S) and coemulsifier (cosurfactant - CoS) of 1:1:2:1 (mass ratio) (fig.2).

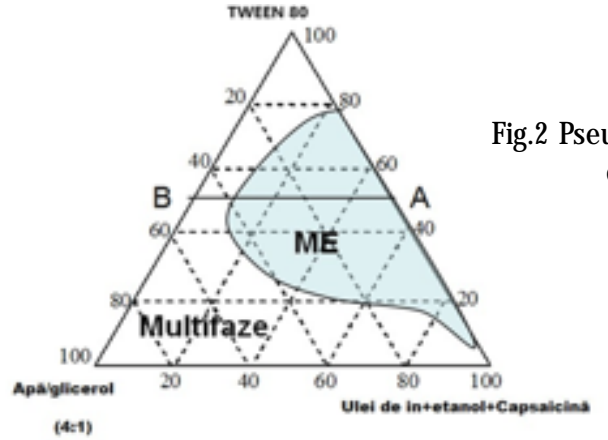

Viscosity was measured (fig.3). The existence of the tw o peaks in the viscosity curve with the increase of water content explains the passage of the system through the three states: microemulsion W/O, bicontinuous structure, and microemulsion $\mathrm{O} / \mathrm{W}$.

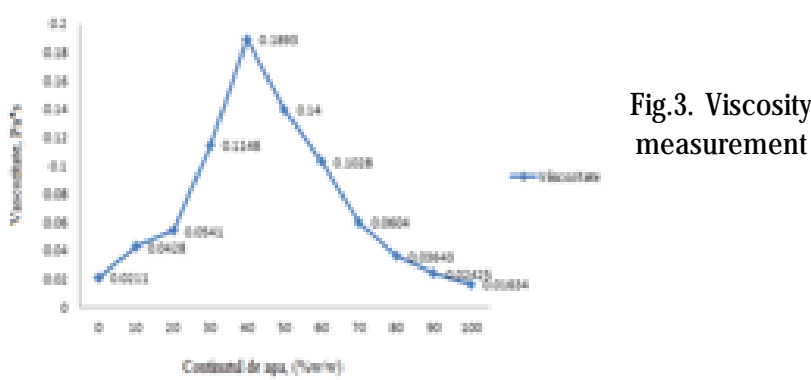

Electrical conductivity is measured (fig.4). These variations are the expression of the transition from $\mathrm{W} / 0$ microemulsions with low conductivity, to O/W microemulsions, where the continuous aqueous phase increases conductivitv.

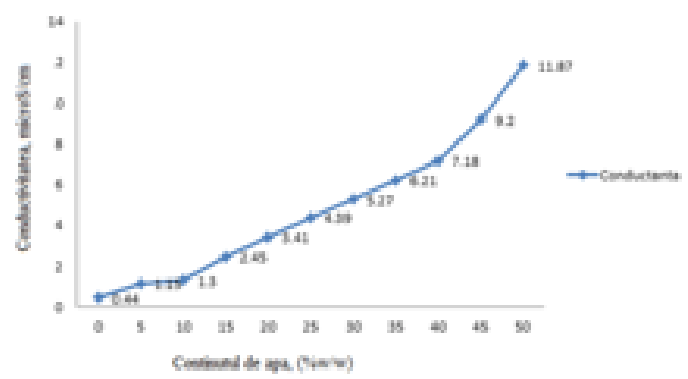

Fig.4.Electrical conductivity measurement

The emulsion type we determined was W/O.

The stability of the microemulsion was determined as compared to ointments. In order to shorten the time necessary to study the stability of pharmaceutical preparations, the emulsion and ointment bases were subjected to unfavourable conditions, and extreme stress conditions respectively, by means of high temperatures (boiling), and low temperatures (freezing).

A temperature stability study was initiated for the capsaicin microemulsions and ointment bases the capsaicin microemulsions maintained their characteristics for 6 months after preparation, without alterations in colour ,homogeneity and transparency. The capsaicin ointment bases remained stable for 6 w eeks. 
As a result of the studies, it was found that their stability was also preserved in case of temperature variations.

After freezing and bringing back to room temperature, both the microemulsion and the ointment bases containing capsaicin kept their homogeneous structure withoutphase separation.

\section{Releasing capsaicin from microemulsion and ointment} bases

In vitro experiments regarding the release and permeation of capsaicin from the samples analysed were carried out by means of a Franz diffusion cell, in stationary mode, using a cellulose membrane as a penetration barrier. The cell has a diffusion area of $2 \mathrm{~cm}^{2}$ and a receptor volume of $5 \mathrm{~mL}$. As a receptor environment we used a mixture 1:1 (v/v) ethanol/buffer citrate-phosphate $\mathrm{pH} 7$ (Wang). In the donor compartmentwe added $1.755 \mathrm{~g}$ formula III capsaicin sample, and $5 \mathrm{~mL}$ microemulsion respectively, covering them with a paraffin film. The liquid in the receptor was thermostated at $37^{\circ} \mathrm{C}$ and continuously stirred with an electromagnetic agitator. Every $10 \mathrm{~min}$ a $2 \mathrm{~mL}$ sample was taken from the receptor liquid, and the same volume of fresh solution was added in the same place. The spectrometry samples UV-Vis were examined, calculating the cumulative capsaicin amount per area unit of the cellulose membrane $\left(\mu \mathrm{g} . \mathrm{cm}^{-2}\right)$.

The Franz cell (fig.5) adapted and used in our experiment consists of a donor space, where the sample to analyse is administered, and a receptor space where the tampon solution phosphate- citric acid pH 7.4 is introduced and the active substance (capsaicin) concentration releaced in time is determined.

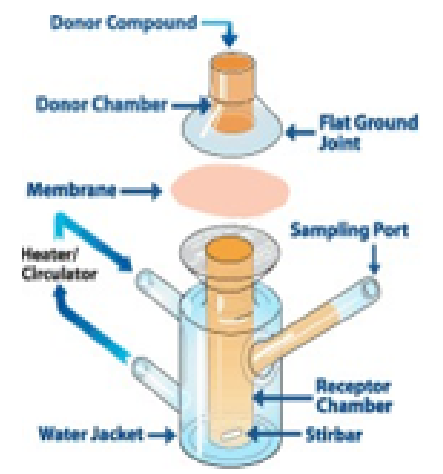

Fig.5. Franz cell

\begin{tabular}{|c|c|c|c|c|c|c|c|}
\hline \multirow{3}{*}{$\begin{array}{l}\text { Gram negative } \\
\text { bacteria }\end{array}$} & \multicolumn{2}{|c|}{$\begin{array}{l}\text { Micro- } \\
\text { emulsion }\end{array}$} & \multirow{2}{*}{$\begin{array}{c}\text { Alcohol } \\
96^{\circ}\end{array}$} & \multirow{2}{*}{ Gentamicin } & \multicolumn{3}{|c|}{ Ointment bases } \\
\hline & $1 \%$ & $5 \%$ & & & I & II & III \\
\hline & \multicolumn{7}{|c|}{ Diameter of inhibition area (mm) } \\
\hline $\begin{array}{l}\text { Enterobacter } \\
\text { hormaechei } \\
\text { (EnteB) }\end{array}$ & 10 & 12 & 6 & 20 & 0 & 0 & 0 \\
\hline $\begin{array}{l}\text { Escherichia coli } \\
\text { (EC) }\end{array}$ & 0 & 12 & 6 & 17 & 8 & 0 & 0 \\
\hline $\begin{array}{l}\text { Pseudomonas } \\
\text { aeruginosa }(P A)\end{array}$ & 12 & 14 & 8 & 30 & 11 & 10 & 12 \\
\hline
\end{tabular}

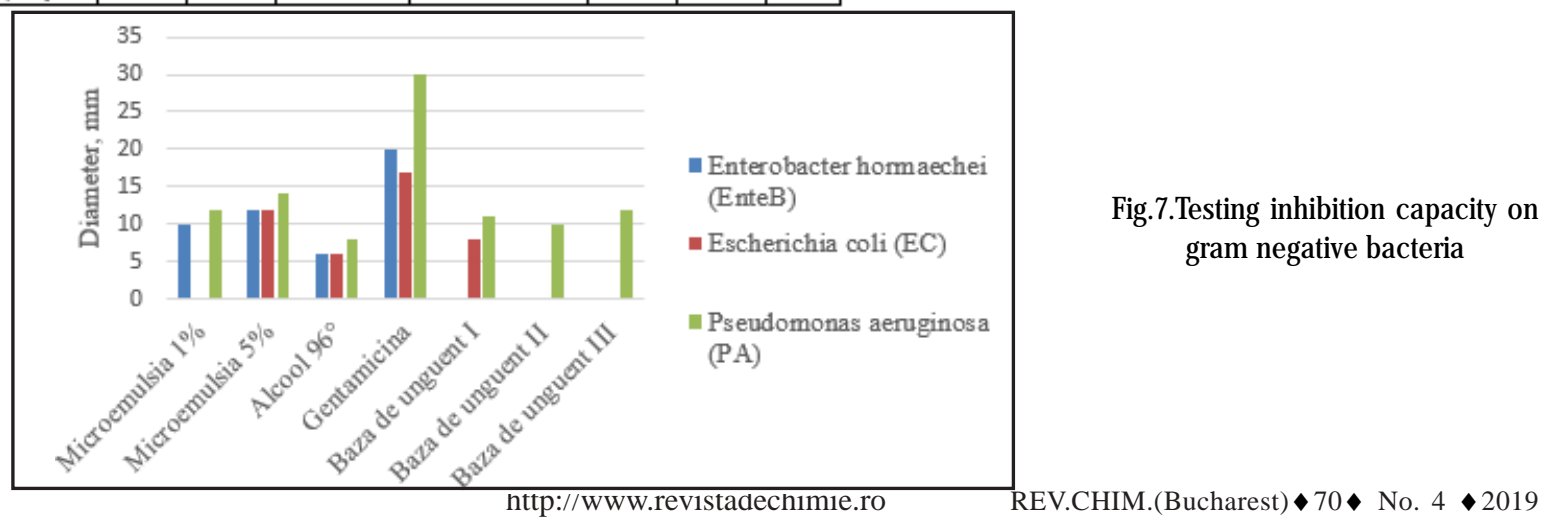

It may be concluded that during the interval $0-60 \mathrm{~min}$ the release takes place according order 1 kinetics (fig.6).

Similarly, it was noted that capsaicin release is better in microemulsion as compared to ointment bases (table 2).

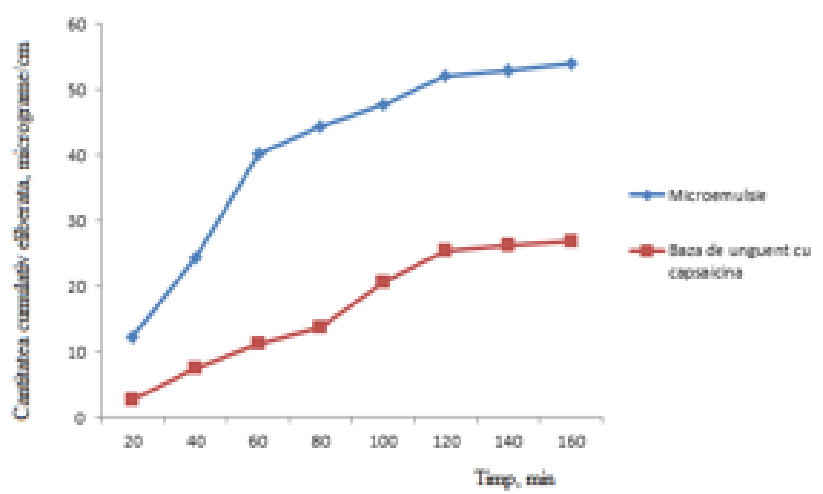

Fig.6.Release of capsaicin microemulsion and ointment

Table 2

VARIOUS FORMULAS OF CAPSAICIN RELEASE

\begin{tabular}{|c|c|c|}
\hline Time, min & $\begin{array}{l}\text { Microemulsion } \\
\left(\mu \mathrm{g} / \mathrm{cm}^{2}\right)\end{array}$ & $\begin{array}{l}\text { Capsaicin ointment } \\
\text { base }\left(\mu \mathrm{g} / \mathrm{cm}^{2}\right)\end{array}$ \\
\hline $\mathbf{2 0}$ & 12.346 & 2.739 \\
\hline 40 & 24.427 & 7.485 \\
\hline 60 & 40.233 & 11.249 \\
80 & 44.367 & 13.873 \\
\hline 100 & 47.862 & 20.722 \\
120 & 52.219 & 25.361 \\
\hline
\end{tabular}

Determination of antimicrobial activity

In order to assess the antimicrobial activity of capsaicin by the diffusimetric method we measured the diameter of the inhibition areas in the microemulsions and ointment bases under analysis.

The results obtained upon analysing the antimicrobial activity of capsaicin microemulsions and ointment bases on Gram negative bacteria are seen in table 3, figure 7and figure 8.
Table 3

ANTIMICROBIAL ACTIVITY OF MICROEMULSIONS, ALCOHOL, OINTMENT BASES AND GENTAMICIN ON SOME GRAM NEGATIVE BACTERIA 


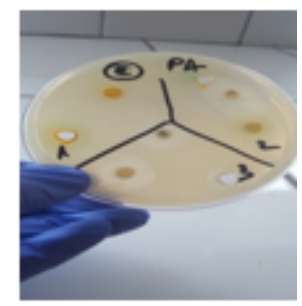

Fig.8.Activitaty on gram negative germs

Table 4

ANTIMICROBIAL ACTIVITY OF MICROEMULSIONS, ALCOHOLS, OINTMENT BASES AND GENTAMICIN ON SOME GRAM POSITIVE BACTERIA

\begin{tabular}{|c|c|c|c|c|c|c|c|}
\hline \multirow{3}{*}{$\begin{array}{l}\text { Microbial } \\
\text { strains }\end{array}$} & \multicolumn{2}{|c|}{ Microemulsion } & \multirow{2}{*}{$\begin{array}{l}\text { Alcohol } \\
96^{\circ}\end{array}$} & \multirow{2}{*}{ Gentamicin } & \multicolumn{3}{|c|}{ Ointment bases } \\
\hline & $1 \%$ & $5 \%$ & & & I & II & III \\
\hline & \multicolumn{7}{|c|}{ Diameter of inhibition area (mm) } \\
\hline $\begin{array}{l}\text { Staphylococcus } \\
\text { aureus (SA) }\end{array}$ & 0 & 8 & 10 & 16 & 0 & 0 & 0 \\
\hline $\begin{array}{l}\text { Streptococcus } \\
\text { pyogenes (Spy) }\end{array}$ & 22 & 25 & 14 & 20 & 8 & 11 & 14 \\
\hline $\begin{array}{l}\text { Streptococcus } \\
\text { pneumoniae } \\
\text { (Spn) }\end{array}$ & 17 & 19 & 10 & 16 & 7 & 9 & 12 \\
\hline $\begin{array}{l}\text { Enterococcus } \\
\text { casseliflavus } \\
\text { (EnteC) }\end{array}$ & 0 & 0 & 0 & 12 & 0 & 0 & 0 \\
\hline
\end{tabular}

The highest antimicrobial activity on some Gram negative bacteria was registered for the $5 \%$ capsaicin microemulsion -bacteria Enterobacter hormaechei and Pseudomonas aeruginosa, and the lowest antimicrobial activity was seen in ointment bases I, II and III upon EnteB and EC.

The antimicrobial activity of microemulsions and ointment bases upon some Gram positive bacteria are shown in table 4, figure 9 and figure 10.

The $5 \%$ microemulsion had better antimicrobial activity on the Streptococcus pyogenes bacteria (diameter of the inhibition area $25 \mathrm{~mm}$ ) as compared to the $1 \%$ microemulsion (diameter of the inhibition area $22 \mathrm{~mm}$ )

When using ointment bases, the activity of formula III (inhibition diameter $14 \mathrm{~mm}$ ) was slightly superior to the efficiency of formulas I and II (diameters $8 \mathrm{~mm}$, and 11 $\mathrm{mm}$ respectively).

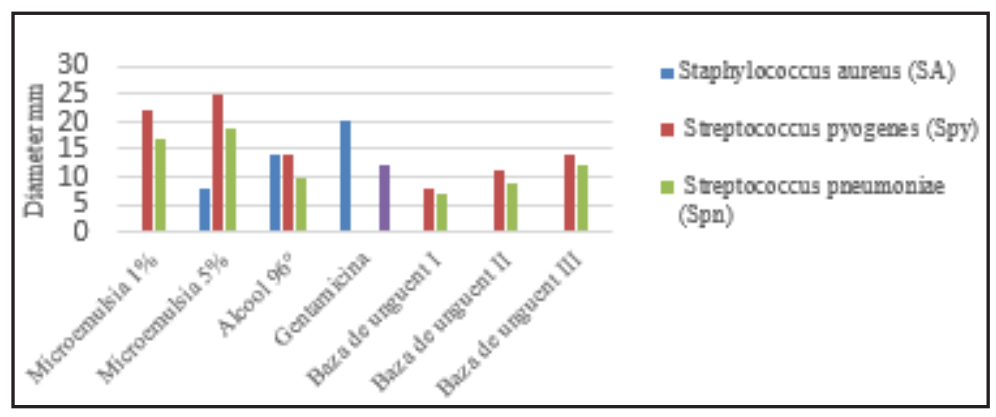

Fig.9.Inhibition capacity on Gram positive germs

\begin{tabular}{|c|c|c|c|c|c|c|c|}
\hline \multirow{3}{*}{ Fungi } & \multicolumn{3}{|l|}{ Microemulsion } & \multirow{8}{*}{$\begin{array}{c}\text { Alcohol } \\
96^{\circ}\end{array}$} & Fluconazole & \multicolumn{3}{|c|}{ Ointment bases } \\
\cline { 2 - 4 } & $1 \%$ & $5 \%$ & & & I & II & III \\
\cline { 2 - 6 } & \multicolumn{8}{|c|}{ Diameter of inhibition area (mm) } \\
\hline Candida albicans & 0 & 12 & 5 & 20 & 0 & 0 & 0 \\
\hline
\end{tabular}

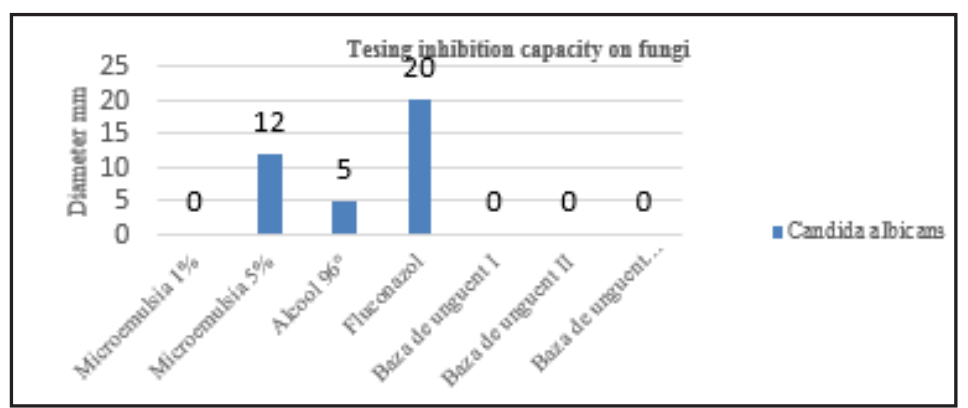

Table 5 and figure 11 show data on the antimicrobial activity of capsaicin microemulsions and ointment bases, alcohol $96^{\circ}$ and fluconazole on the Candida albicans fungus.

According to the data in figure 11, in case of the Candida albicans fungus, fluconazole had a remarkable antimicrobial potential (inhibition area diameter $20 \mathrm{~mm}$ ), unlike the microemulsion and ointment bases, which had smaller inhibition diameters (inhibition area diameter 12 $\mathrm{mm}$, and $0 \mathrm{~mm}$ respect

The results of the study show that the $5 \%$ microemulsion had a higher antimicrobial activity than ointment bases, but inferior to gentamicin and fluconazole.

Ethyl alcohol $96^{\circ}$ showed a low antimicrobial effect, but in association to the microemulsion under study it led to favourable results. 


\section{Conclusions}

It was found that the microemulsion under study is of the water in oil type (W/O), proving that the capsaicin microemulsion scored higher in temperature variation as compared to ointment bases, thus it may be considered that the microemulsion has better stability in time without propertyalteration.

It was evinced that there is better capsaicin in microemulsion as compared to ointment bases by means of the Franz diffusion cell, using a cellulose membrane as a penetration barrier.

The study proved that the microemulsion has a much higher antimicrobial activity than the ointment bases, but lower than gentamicin and fluconazole in case of reference microorganisms. Taking these results into account, it may be concluded that the microemulsion pharmaceutical form may include other active substances or natural oils like lavender, which may be a future method of destroying the bacteria in nosocomial infection, as well as a possible modulation of endosymbiont proliferation in various skin conditions like acne or rosacea (but taking into consideration the potential for local irritative action and only after the informed patient's consent for testing) [ $25,28]$. Another research direction could be the use in pilar conditions like alopecia areata, or diffuse alopecia, on their own or associated to other conditions, including autoimmune or pregnancy-induced, observing the ethics of medical research $[27,28]$ Also, microemulsions could be obtained using natural extractive Kombucha solutions which are also remarkably effective in dealing with this type of microorganisms. Formulating microemulsions is a means to solve solubilisation problems and increase the bioavailability of medicinal substances.

\section{References}

1.GRIGORE BALANESCU, Dicionar de chimie, Editura Tehnicã, Bucuresti, 1964

2.LORNA MASON, R ANDREW MOORE, SHEENA DERRY, JAYNE E EDWARDS, HENRY J MCQUAY. Systematic review of topical capsacin for the treatment of chronic pain. BMJ 2004; 328:991

3.MARTINDALE. The Complete Drug Reference, 38 edition 2014 (2 Volume Set)

4.LEA V. WEBER, KLAUDIA AL-REFAE, GERHARD WOLK, GABRIELE BONATZ, JANINE ALTMULLER, CHRISTIAN BECKER, Gunter Gisselmann, Hanns Hatt: Expression and functionality of TRPV1 in breast cancer cells, in: Breast Cancer - Targets and Therapy, 2016, DOI: $10.2147 / B C T T . S 121610$

5.IRINA MIRELA APETREI, ADRIANA AURORA BEJ INARU, MONICA BOEV, CONSTANTIN APETREI, DUMITRIU BUZIA O.,Determination of ibuprofen based on screen-printed electrodes modified with carbon nanofibers, Farmacia, 2017, vol. 65, 5,p.790-795

6.NICULET, E., NECULIA, G.V., TATU, A.L., DUMITRIU BUZIA, O., Curcumin- Extraction, Physical and Chemical Analysis, Formulas and Control. Basic Methods for Further Research. Mat.Plast., 55, no 4, 2018,p.672-675

7.DUMITRIU BUZIA, O., MARDARE, N., FLOREA, A., DIACONU, C., DINICA, R.M.,TATU,A.L., Formulation and preparation of pharmaceuticals with anti-rheumatic effect using the active principles of capsicum annuum and piper nigrum, Rev. Chim. (Bucharest), 69, no. 10,2018 , p. 2854-7

8.KNOTKOVA H., PAPPAGALLO M., SZALLASIA A., 2008, Capsaicin (TRPV1 Agonist) therapy for pain relief: farewell or revival, Clin J Pain, 24 (2): 142-154

9.GHEORGHEI,TATU AL,LUPU I, THAMER O,COTAR AI,PIRCALABIORU GG,POPA M,CRISTEA V.C,LAZAR V, CHIFIRIUC MC. Molecular characterization of virulence and resistance features in Staphylococcus aureus clinical strains isolated from cutaneous lesions in patients with drug adverse reactions. Rom Biotech Lett. 2017;22(1):12321-27
10.NWABUDIKE, L.C. , TATU A.L Reply to Gambichler T et al.: Altered epigenetic pathways and cell cycle dysregulation in healthy appearing skin of patients with koebnerized squamous cell carcinomas following skin surgery. J Eur Acad Dermatol Venereol $2019 ; 33(1)$ :e3-e

11.PRICOP R,CRISTEA VC, GHEORGHE I, TATU AL, MIHAESCU G,CHIFIRIUC MC. Matrix-assisted laser desorption/ionization timeof-flight mas spectrometry (MALDI-TOF MS) reveals the anaerobic Slakia exigua as unique etiology of a dental abscess. Biointerface Res. Appl. Chem.2017; 7( 2):1995-1997

12.CIOBOTARU O.C, CIOBOTARU O.R, VOICU DR, BARNA O, BARNA I,VOINESCU DC. Postoperative pain after total abdominal hysterectomy and bilateral salpingooophorectomy depending on the type ofanaesthesia administration. Biotechnology \&Biotechnological Equipment. 2016.30;2: 341-345

13.NWABUDIKE, L.C., ELISEI, A.M., DUMITRIU BUZIA, O., MIULESCU, M., TATU, AL., STATINS. A Review on Structural Perspectives, Adverse Reactions and Relations with Non-melanoma Skin Cancer, Rev.Chim. (Bucharest), 69, no. 9, 2018, p. 2557-2562

14.NWABUDIKE, LC, TATU, AL , Response to - Chronic exposure to tetracyclines and subsequent diagnosis for non-melanoma skin cancer in a large Mid-Western US population. J Eur Acad Dermatol Venereol. 2018;32(4):e 15

15.TATU, AL.,CIOBOTARU, O.R., MIULESCU, M., DUMITRIU BUZIA ,O., ELISEI, A.M., MARDARE, N.,DIACONU, C., ROBU, S., NWABUDIKE, LC,. Hydro-chlorothiazide: Chemical Structure, Therapeutic, Phototoxic and Carcinogenetic Effects in Dermatology, Rev.Chim. (Bucharest), 68, no. 8, 2018, p. 2110-2114

16.ARDELEANU, V., DOBRE, M., GEORGESCU, EM., Deep Facial Wrinkle Treatment Outcome After First Injection of Reticulated Hyaluronic Acid.Rev. Chim. (Bucharest), 66, no. 12, 2015, p. 21292131

17.CIOBOTARU O.R, VOINESCU D.C, BARNA O, BARNA I CIOBOTARU O.C. Influence of the type of anaesthesia used, the diet and the consumption of sugar and alcohol onthe intradermal skin test to morphine. Biotechnology \& Biotechnological Equipment. 2015. 29:5,935-941.

18.TATU AL-Topical Steroid Induced Facial Rosaceiform Dermatitis Acta Endo (Buc) 2016 12: 232-233

19.BRANISTEANU DE, BRANISTEANU D.C, STOLERIU G, FERARIU D, VOICU CM, STOICA LE, CÃRUNTU C, BODA D, FILIP-CIUBOTARU FM, DIMITRIU A, RADU CD. Histopathological and clinical traps in lichen sclerosus: a case report. Rom J MorpholEmbryol. 2016;57(2Suppl):817823

20.ARDELEANU, V., BERBECE, S.I., FLORESCU, I.P, JECAN, RC., The Use of Hyaluronic Acid Combined with Teosyal Redensity II for the Treatment of Dark Circles Under the Eyes, Mat. Plast.,54, no. 1, 2017, p. 37-40

21.TATU AL, IONESCU MA, NWABUDIKE LC Contact allergy to topical mometasone furoate confirmed by rechallenge and patch test. Am J Ther. 2018;25(4):e497-e498

22.HUNTER GRONINGER, M.D. RANDALL E. SCHISLER, M.D. - J ournal of Palliative Medicine-Topical Capsaicin for Neuropathic Pain \#2552012 - https://www.ncbi.nlm.nih.gov/pmc/articles/PMC3462404/

23.DUMITRIU BUZIA OLIMPIA, MARDARE N., Tehnologie farmaceuticã II, Galai, România, Ed. Zigotto, 2013, 57-64, ISBN: 978-606-669-021-8.

24.POPESCU M., CHIUTU L., MIRCIOIU C., DIMA S., Capsaicin microemulsions: preparation, characterizationand in vitro release study. Farmacia, 2014; 62(1):p.58-68

25.CLATICI VC, GEORGESCU O, DRAGANITA AMV, TATU AL, FICA S. Milk and Insulin Growth Factor 1 (IGF1) - Implication in Acne and General Health.Rom Biotech Lett. 2015;20(1):10013-25

26.DRÉNO B, PÉCASTAINGS S, CORVEC S, VERALDI S, KHAMMARI A, ROQUESC. Cutibacterium acnes (Propionibacterium acnes) and acne vulgaris: a brief look at the latest updates. J Eur Acad Dermatol Venereol. 2018 Jun;32 Suppl 2:5-14

27.PURCARU D, PREDA A, POPA D, MOGA MA, ROGOZEA L. Informed Consent: How Much Awareness Is There? PLoS One. 2014;9(10):e110139 28.ROGOZEA LM , DIACONESCU DE, DINU EA; ET AL. Bioethical dilemmas in using animal in medical research. Challenges and opportunities.Rom J Morphol Embryol 2015; 56(3): 1227-31 